\title{
HADIS-HADIS EKOLOGI DALAM KONTEKS PERINDUSTRIAN DI INDONESIA
}

\author{
Agus Firdaus Chandra \\ Fakultas Sains dan Teknologi UIN Sulthan Syarif Kasim Riau \\ Jl. H.R. Soebrantas KM. 15,5 Panam - Pekanbaru \\ e-mail: agus.firdaus.chandra@uin-suska.ac.id
}

\begin{abstract}
As the religion of rabmatan lil 'alamin, Islam does not only concern with how mankinds worship to Allah (ibadah), and establish relationship among mankinds (muamalah) but also protect and preserve ecological systems around them as main purposes of Islamic laws (maqashid al-syariab). As the best role model (uswah al-hasanah), Prophet Muhammad pbuh has shown especially how to deal with ecology in relation to industrial activities. As a predominantly Moslem country, hadeeth as a religious text is expected to a great influence on the way of life including industrial world in order to realize public welfare and prosperity by industrial practitioners in Indonesia in general. However, religious passion has not had a positive impact in industrial world. Welfare as the main goal can only be enjoyed by a small group of people. Dealing with the phenomena, this article, therefore, aims at discussing hadeeths in relation to ecology and presenting analysis the implementation of the hadeeths in industrial practices in Indonesia
\end{abstract}

Kata kunci: ekologi, alam, lingkungan, industri

\section{PENDAHULUAN}

$I$ slam adalah agama rahmatan lil 'alamin. Tidak hanya menjaga hubungan antara manusia dengan penciptanya (ibadah), atau antara manusia dengan sesamanya (muamalah), Islam juga menjaga hubungan antara manusia dengan ekosistem yang ada di sekelilingnya. Menjaga kondisi ekologi termasuk bagian dari menjaga harta yang merupakan salah satu dari tujuan pokok syariah (maqashid al-syari'ah). Harta yang dimaksud bukan dalam arti sempit, akan tetapi segala sesuatu yang membuat manusia cenderung/suka padanya dan berusaha untuk mendapatkannya termasuk di dalamnya lingkungan alam yang ada di sekeliling kita. (Yusuf al-Qardhawi, 2001: 51)

Alquran telah menyinggung halhal yang berkaitan dengan ekologi (hubungan antara makhluk dan lingkungan), seperti menjaga lingkungan dari kerusakan, keseimbangan dalam produksi, larangan eksploitasi dan lainlain. Peran Nabi Muhammad Saw sebagai penjelas dari Alquran terkait hal ini juga patut untuk ditelisik. Sebagai contoh terbaik yang diturunkan oleh Allah Swt untuk umat manusia, Rasulullah Saw tentunya juga punya petunjuk-petunjuk terhadap hal ini.

Perindustrian adalah salah satu sektor utama pembangunan perekonomian di Indonesia, tak dapat dipungkiri bahwa perkembangan jumlah proyek-proyek industri semakin meningkat dari tahun ke tahun. Hanya saja perkembangan kuantitas ini meninggalkan dampak negatif terhadap ekosistem yang ada. Climate change dan global warming akibat pembabatan liar dan 
kebakaran hutan merupakan contoh dari sekian banyak krisis lainnya. Industrialisasi tidak hanya berpengaruh pada krisis ekologi akan tetapi juga menjalar pada krisis sosial masyarakat seperti perubahan perilaku dan meningkatnya angka kriminal.

Sebagai rule of law dalam Islam, sejauh mana konsep yang diajarkan oleh Nabi Muhammad Saw dalam mengatur kondisi ekologi dalam kegiatan produksi, dan sejauhmana peran agama dalam dunia industri di Indonesia? Tulisan ini diharapkan dapat mempengaruhi pola pikir masyarakat Indonesia yang notabene merupakan mayoritas muslim melalui pemahaman teks-teks keagamaan yang dalam hal ini adalah Hadis terutama para pelaku industri. Pada bagian awal dituliskan Hadis-hadis yang berkaitan dengan ekologi dan pemahamannya. Selanjutnya dilakukan analisis terhadap sejauh mana penerapan Hadis-hadis tersebut dalam dunia perindustrian di Indonesia.

\section{KONSEP EKOLOGI ALA NABI MUHAMMAD SAW}

\section{Motivasi Produksi: Kesejahteraan Umat}

Segala perbuatan bergantung pada niat, dan setiap orang akan mendapatkan apa yang ia niatkan. (Al-Bukhari, 1400: 13) begitulah Islam menempatkan pentingnya niat dalam setiap pekerjaan. Dan di balik setiap niat tersisip sebuah tujuan menghambakan diri pada Allah Swt dan sebaliknya, Allah Swt dan utusan-Nya juga memberikan berita gembira plus ganjaran bagi setiap pelaku kebaikan termasuk menjaga kelestarian alam.
Islam mendorong umatnya untuk senantiasa menjaga lingkungan dan salah satunya dengan menanam dalam arti yang sangat luas, sebagaimana disebutkan dalam Hadis di bawah ini:

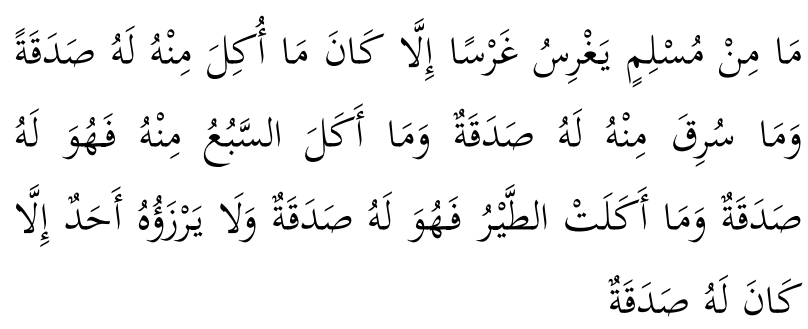

Tidaklah seorang muslim yang bercocok tanam, kecuali setiap tanaman yang dimakannya bernilai sedekah baginya, yang dicuri orang darinya menjadi sedekah baginya, yang dimakan binatang liar menjadi sedekah baginya, yang dimakan burung menjadi sedekah baginya, dan tidaklah seseorang mengambil darinya, melainkah menjadi sedekah baginya (Muslim, 1991:3/1188).

Menanam sesuatu layaknya bersedekah bagi seorang muslim baik hasil dari tanaman tersebut bermanfaat secara langsung baginya atau tidak. Dengan menanam sesuatu, secara tidak langsung kita juga sudah menjaga ekosistem lain yang mengambil manfaat dari apa yang kita tanam. Menanam sesuatu berarti menjaga kelangsungan flora dan fauna sekaligus. Dengan kata lain, dengan menanam maka kesejahteraan semua makhluk yang ada di lingkungan tersebut akan terjaga dengan baik. Begitu pentingnya hal ini, Rasulullah Saw menyuruh umatnya senantiasa melakukan hal tersebut bahkan walau kiamat sudah di depan mata. Rasulullah Saw bersabda:

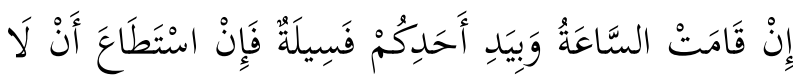

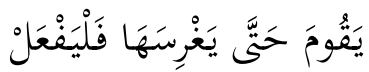


Jika terjadi hari kiamat sedang salah seorang dari kalian mempunyai bibit kurma, jika mampu hendaklah jangan berdiri sampai dia menanamnya. (Musnad Ahmad, 1999: 20/296)

Tidak hanya ganjaran pahala sedekah yang diterima, Rasulullah Saw juga mengapresiasi dan memberikan hak kepemilikan terhadap orang yang bertanam pada lahan yang kosong atau lahan yang tak bertuan. Hal tersebut dapat kita lihat pada Hadis berikut:

$$
\text { مَنْ أَعْمَرَ أَرْضًا لَيَسَتْ لِأَحَدِ فَهُهَ أَحَقُّ }
$$

Siapa yang memanfaatkan tanah yang tidak ada pemiliknya (tanah tak bertuan), maka orang itu yang paling berhak atasnya. (AlBukhari, 1400: 2/157)

Kata "siapa" pada Hadis di atas menunjukkan umum tak terbatas. Hanya saja informasi ini tentunya terlebih dahulu diprioritaskan untuk orang-orang yang berada dalam lingkungan masyarakat Rasulullah Saw. Kebijakan ini juga diperjelas dengan praktek Umar Ra pada masa pemerintahannya. Perlu diketahui bahwa Rasulullah Saw dan Umar Ra adalah pemimpin Negara yang menguasai, mengatur, dan mengawasi wilayah kekuasaannya. Dengan demikian hak pengelolaan lahan tersebut diprioritaskan bagi rakyat yang berada di bawah kekuasaannya. Mereka menuntun rakyatnya menuju kesejahteraan dengan mendorong mereka untuk melakukan kegiatan produksi serta langsung mengapresiasi mereka dengan memberikan hak kepemilikan atas lahan tersebut. Bahkan lebih tegas lagi, Rasulullah Saw juga menyuruh sahabat yang memiliki tanah untuk bertanam, atau memberikan pada sahabat lain jika tanah tersebut tidak diolah, sebagaimana terdapat pada Hadis di bawah ini:

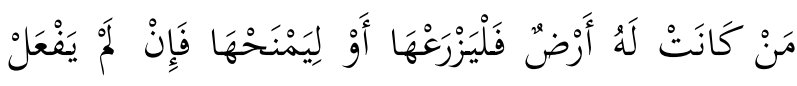

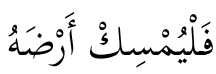

Siapa yang memiliki tanah ladang hendaklah dia garap untuk bercocok tanam atau dia hibahkan. Jika dia tidak lakukan maka hendaklah dia menahan tanahnya. (Al-Bukhari, 1400: 2/158)

A'mara pada Hadis sebelumnya bermakna memakmurkan secara umum termasuk di dalamnya berbagai macam jenis dunia perindustrian seperti perkebunan, pertambangan, dan lain-lain. Rasulullah Saw pernah memberikan sebidang tanah pertambangan pada Bilal ibn al-Harits meskipun beberapa tahun kemudian Umar Ra mengambil kembali lahan tersebut setelah tidak dimanfaatkan selama tiga tahun. Untuk lebih jelasnya dapat dilihat Hadis berikut:

عَنْ بِلاَلِل بْنِ الحَارِثِ: أَنَّ رَسُولَ اللَّهِ -صلى الله عليه

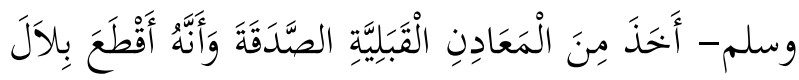

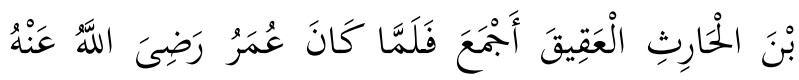

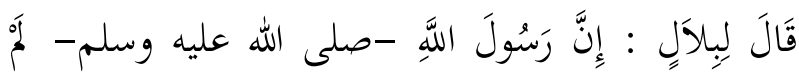

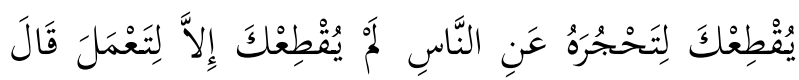

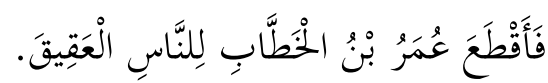

Dari Bilal Ibn al-Haris bahwasanya Rasulullah Saw mengambil zakat pada pertambangan al-qabaliyyah dan Rasulullah Saw. memberikan Bilal Ibn Haris sebuah lembah, dan pada masa 'Umar Ibn alKhaththab, ia berkata pada Bilal: Sungguh Rasulullah Saw tidak memberikanmu lahan pertambangan hingga tidak bermanfaat bagi manusia lain, akan tetapi 
agar engkau mempunyai pekerjaan. Bilal berkata: Umar pun membagikan lembah tersebut pada masyarakat. (Al-Baihaqi, 1989: 2/328).

Kegiatan produksi yang dilakukan oleh manusia juga harus menjaga keseimbangan antar sesama ekosistem yang ada termasuk manusia itu sendiri. Kegiatan produksi pada dasarnya mengantarkan manusia menuju kesejahteraan hidup dan jauh dari kelaparan sebagaimana tujuan dasar diperuntukkannya alam bagi manusia. Sebagaimana do'a Rasulullah Saw:

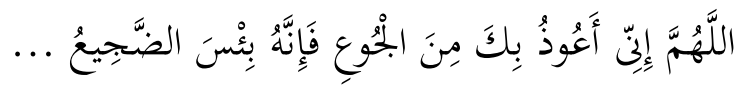

Ya Allah aku berlindung kepadaMu dari kelaparan, karena itu adalah seburuk-buruk teman tidur. (Abu Daud, 1998: 2/306)

Dengan menjaga keseimbangan antara produksi dan menjaga alam sebagai sumber daya sekaligus akan mengantarkan kita pada tujuan utama yaitu kesejahteraan yang berkesinambungan. Produksi yang tidak mempertimbangkan keadaan alam akan berhenti pada saat sumber daya alam tersebut habis. Dampaknya, alam juga akan mengalami pencemaran dan kerusakan yang juga mengantarkan kita pada ketidaksejahteraan.

\section{Ihsan Tanpa Kerusakan}

Ihsan adalah bahasa agama yang artinya berbuat lebih baik dan bersungguh-sungguh dalam hal itu. Sesuai dengan jawaban Rasulullah Saw terhadap pertanyaan Jibil: "Engkau menyembah Allah seolah-olah engkau melihat Allah Swt"(Al-Bukhari, 1400: 13). Berbuat baik saja tidak cukup, dan merasakan pengawasan Allah Swt sangat penting, baik karena takut azab-Nya, atau inginkan rida-Nya. Rasulullah Saw bersabda:

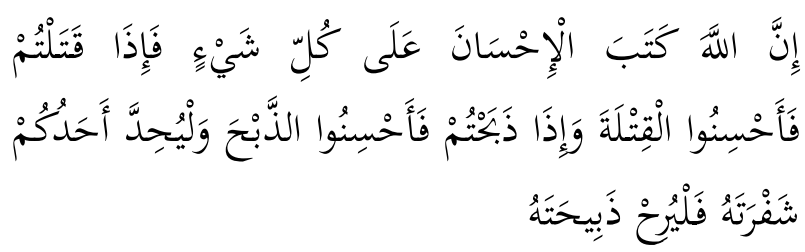

Sesungguhnya Allah telah mewajibkan supaya selalu bersikap baik terhadap setiap sesuatu, jika kamu membunuh maka bunuhlah dengan cara yang baik, jika kamu menyembelih maka sembelihlah dengan cara yang baik, tajamkan pisaumu dan senangkanlah hewan sembelihanmu. (Muslim, 1991: 3/1548).

Ihsan wajib dalam segala perbuatan, bahkan pada perkara-perkara yang mengerikan dan menjijikkan seperti halnya membunuh dan menyembelih. Islam menghargai naluri alami pada binatang ternak yang juga merasakan sakitnya kehilangan nyawa. Oleh karena itu untuk menyembelihpun dianjurkan untuk menajamkan mata pisau dan menenangkan hewan sembelihan hingga mati dengan tenang.

Islam sangat menjaga keseimbangan antara produksi dan pelestarian alam. Pelestarian tidak mutlak bermakna menjaga lingkungan tanpa memanfaatkannya, karena segala yang ada di bumi sudah disediakan oleh Allah Swt untuk menjaga kelangsungan hidup manusia. Sedangkan produksi juga tidak berarti memanfaatkan hasil alam tanpa memperhatikan kelestariannya. Dua hal ini harus seimbang sehingga lingkaran kebutuhan manusia dan alam termasuk hewan dan tumbuhan di dalamnya tetap terjaga dengan baik.

Bentuk dasar berbuat ihsan terhadap lingkungan dan alam sekitar adalah 
kebersihan. Islam melazimkan kebersihan pada setiap kegiatan ibadah dan menilainya setengah bagian keimanan (Muslim, 1991: 1/203). Manusia harus memulai kebersihan dari dirinya karena selain sebagai bagian dari ekosistem yang ada, manusia juga memegang peranan khalifah bagi ekosistem lainnya. Sebagai satu-satunya makhluk Tuhan yang berakal manusia wajib menjaga keanekaragaman hayati yang ada di sekelilingnya. Rasulullah Saw bersabda:

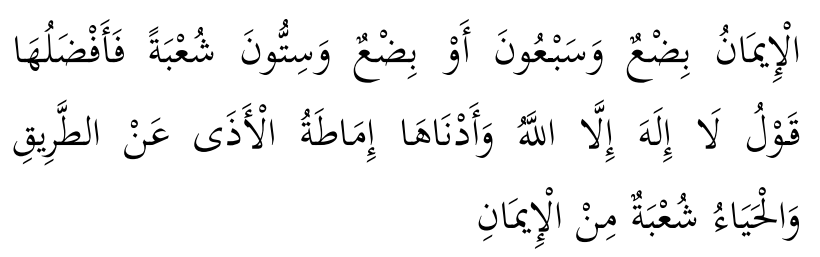

Iman itu ada tujuh puluh tiga sampai tujuh puluh sembilan, atau enam puluh tiga sampai enam puluh sembilan cabang. Yang paling utama adalah perkataan, Tidak ada tuhan yang berhak disembah selain Allah. Dan yang paling rendah adalah menyingkirkan gangguan dari jalan. Dan malu itu adalah sebagian dari iman. (Muslim, 1991: 1/63)

Menghindarkan segala sesuatu yang akan mengganggu atau merusak dari jalan adalah bagian dari iman. Hal ini memberikan keamanan dan kenyamanan terhadap pengguna jalan tersebut baik manusia ataupun hewan. Rasulullah Saw juga melarang umatnya untuk buang air sembarangan, sebagaimana terdapat pada Hadis di bawah ini:

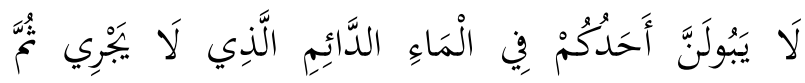

$$
\begin{aligned}
& \text { يَغْتَسِلُ فِيِِ لايه }
\end{aligned}
$$

Janganlah salah seorang dari kalian kencing di air yang menggenang kemudian mandi darinya (Abu Daud, 1998: 1/182) .
Selain dari faktor menjaga kebersihan, air yang tergenang termasuk sumber daya yang bisa dimanfaatkan. Karena kondisinya yang tergenang dan tidak mengalir maka buang air di sana akan memberikan efek buruk terhadap keanekaragaman hayati yang hidup dari air tersebut.

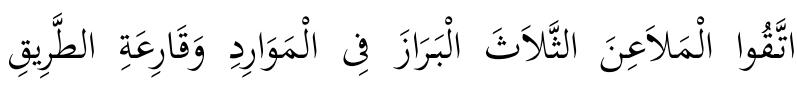

$$
\begin{aligned}
& \text { وَالظِّلِّ }
\end{aligned}
$$

Hindarilah oleh kalian tiga hal terlaknat; buang air besar di sumber air, tengah jalanan, dan tempat berteduh (Abu Daud, 1998, 1/160).

Rasulullah Saw mengingatkan umatnya untuk menghindari laknat terutama bagi orang yang buang air besar sembarangan. Tiga tempat yang disebutkan merupakan bentuk perhatian Rasulullah Saw terhadap kondisi ekologis. Sumber air sebagai sumber kehidupan di mana semua ekosistem yang ada sangat membutuhkan air untuk kehidupan mereka. Jalan merupakan sarana yang dilalui manusia untuk menjalani kehidupan mereka dari satu tempat ke tempat lainnya. Tempat berteduh adalah tempat yang sangat penting untuk melindungi diri baik dari sengatan panas matahari ataupun hujan yang turun.

Selain menjaga kebersihan, merawat kondisi lingkungan agar senantiasa baik dan bersih juga merupakan bagian dari ihsan, baik hewan ataupun tumbuhan. Seorang wanita yang mengurung seekor kucing tanpa makanan hingga mati kelaparan diberitakan masuk neraka (AlBukhari, 1400: 2/166). Sebaliknya seorang laki-laki yang memberi minum seekor anjing yang sangat haus diberikan 
pengampunan dan pahala (Al-Bukhari, 1400: 2/167).

Rasulullah Saw juga melarang orang menato hewan peliharaannya sekalipun untuk menandakan kepemilikannya.

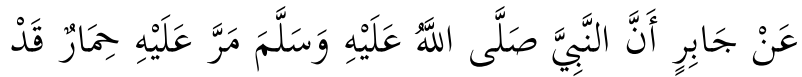

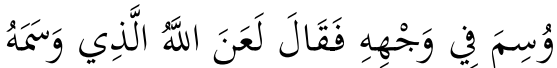

Dari Jabir bahwa seekor keledai yang ditato mukanya pernah lewat di hadapan Rasulullah Saw. Lalu beliau bersabda: 'Allah mengutuk orang yang menatonya.' (Muslim, 1991, 2/1673).

Rasulullah Saw menegur orang yang memisahkan anak burung dari induknya, dan orang yang membakar semut karena tidak ada yang berhak mengazab dengan api kecuali Allah Swt sebagai Sang pemilik api. (Abu Daud, 1998: 5/455). Beliau Saw juga menyebutkan kisah Nabi terdahulu yang membakar sarang semut hanya karena satu gigitan semut (AlBukhari, 1400: 2/364).

Selain memperhatikan hewan, Rasulullah Saw juga memperhatikan tanaman/tumbuhan yang ada di sekelilingnya. Keberadaan pohon di tengah padang pasir yang tandus adalah bentuk keserasian alam yang saling memenuhi kebutuhan makhluk lainnya salah satu bentuknya adalah berteduh dan berlindung. Menebang pohon berarti sama halnya dengan menghilangkan sarana yang bermanfaat baik oleh manusia ataupun hewan-hewan yang ada di sekelilingnya. Oleh karena itu wajar rasanya Rasulullah Saw mengancam orang yang menebang pohon akan dibenamkan oleh Allah Swt di akhirat kelak sebagaimana sabdanya di bawah ini:

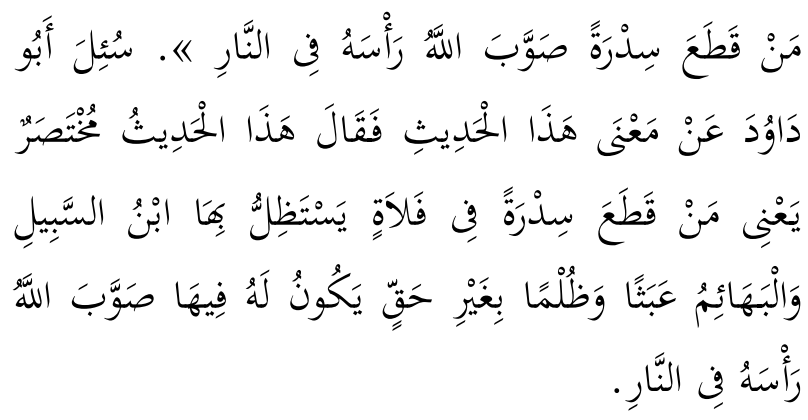

Siapa menebang pohon bidara maka Allah akan membenamkan kepalanya dalam api neraka. Abu Dawud pernah ditanya tentang Hadis tersebut, lalu ia menjawab, "Secara ringkas, makna Hadis ini adalah bahwa barang siapa menebang pohon bidara di padang bidara dengan sia-sia dan zalim; padahal itu adalah tempat untuk berteduh para musafir dan hewan-hewan ternak, maka Allah akan membenamkan kepalanya di neraka. (Abu Daud, 1998: 5/446)

\section{Proporsional dalam Produksi; Tanpa Israf dan Tabzir}

Islam mengajarkan proporsional dalam menggunakan atau memanfaatkan hewan. Rasulullah Saw melarang umatnya berdiri di atas punggung hewan karena itu akan menyakitinya. (Abu Daud, 1998: 3/245). Bahkan di akhirat nanti sapi betina akan meremukkan orang yang menungganginya karena menyalahi fungsi penciptaannya yaitu membajak.

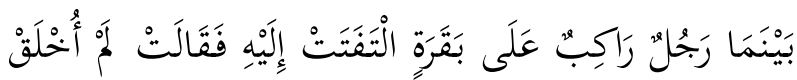

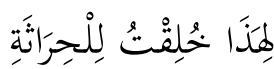

(Pada hari kiamat) penunggang sapi betina akan diremukkan oleh sapi tersebut seraya berkata; Aku diciptakan bukan untuk ini, tapi aku diciptakan untuk membajak (AlBukhari, 1400: 2/153).

Untuk kegiatan produksi Allah Swt telah memperuntukkan apa yang ada di 
bumi untuk kesejahteraan manusia (AlBaqarah 29). Bahkan ada tiga hal pokok yang wajib dimiliki oleh semua manusia dan tidak boleh dimonopoli yaitu rumput yang ada di padang luas, air sebagai sumber utama bagi semua makhluk kehidupan dan api yang tidak kalah pentingnya. Rasulullah Saw bersabda:

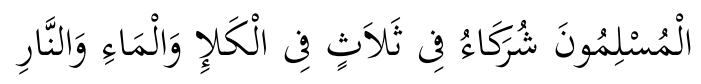

Umat Islam bersekutu dalam hal rumput, air dan api (Abu Daud, 1998: 4/174).

Selain itu, Rasulullah Saw memberikan kebebasan berkreasi dalam aktifitas produksi. Pernah suatu ketika Rasulullah Saw mengomentari sahabat yang mengawinkan korma. Sahabat meninggalkan pengawinan tersebut dan hasilnya berdampak buruk. Namun tetap pada akhirnya Rasulullah Saw memberikan keleluasaan pada sahabat tersebut untuk melakukan yang terbaik bagi tanamannya.

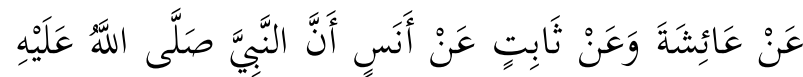

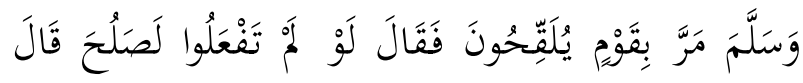

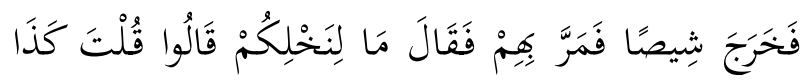

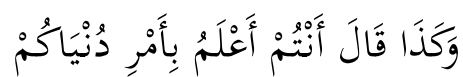

Dari 'Aisyah dan dari Tsabit dari Anas bahwa Nabi Saw pernah melewati suatu kaum yang sedang mengawinkan pohon kurma lalu beliau bersabda: "Sekiranya mereka tidak melakukannya, kurma itu akan (tetap) baik." Tapi setelah itu, ternyata kurma tersebut tumbuh dalam keadaan rusak. Hingga suatu saat Nabi Saw melewati mereka lagi dan melihat hal itu beliau bertanya: 'Ada apa dengan pohon kurma kalian?Mereka menjawab; Bukankah anda telah mengatakan hal ini dan hal itu? Beliau lalu bersabda: Kalian lebih mengetahui urusan dunia kalian' (Muslim, 1991: 4/1836).

Sumber daya alam yang ada juga harus dijaga keseimbangannya. Meskipun jumlahnya masih banyak, manusia tetap harus menggunakannya secara teliti, cermat, dan tidak berlebih-lebihan, bahkan dalam berwudhu' sekalipun.

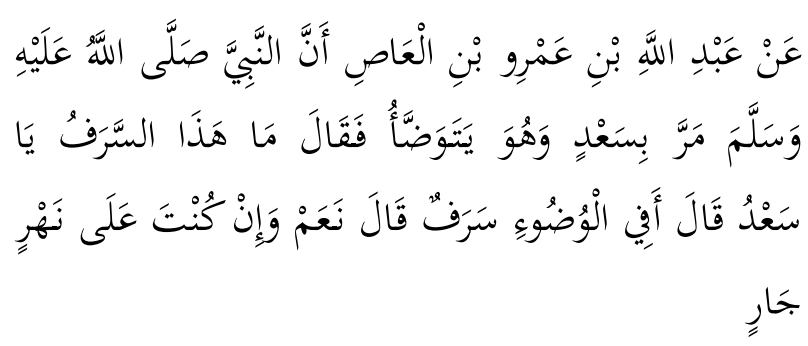

Abdullah bin 'Amru bin Al 'Ash berkata; Nabi Saw pernah melewati Sa'd yang sedang berwudhu, maka beliau bertanya: "Wahai Sa'd, kenapa kamu berbuat israf (berlebih-lebihan)?" Dia berkata; "Apa dalam wudhu juga ada israf?" Beliau menjawab: "Ya, meskipun kamu berada pada sungai yang mengalir" (Ahmad Ibn Hanbal, 1995: 11/636).

Selain dari berlebih-lebihan, Alquran juga memposisikan pelaku sia-sia sama halnya dengan kawan setan. Hasil dari suatu produksi harus dimanfaatkan sebaik mungkin sehingga tidak ada yang terbuang sia-sia, karena setiap sumber daya yang kita gunakan akan dimintai pertanggungjawabannya nanti di akhirat, sebagaimana pada Hadis berikut ini:

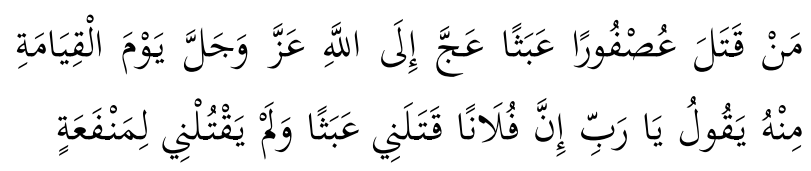

Barangsiapa yang membunuh seekor burung untuk main-main saja, maka burung itu akan mengadu pada hari kiamat nanti kepada Allah 'Azza wajalla dengan seraya berkata, 'Wahai Rabbku, 
sesungguhnya si "A" membunuhku untuk main-main saja bukan untuk suatu manfaat (Ahmad Ibn Hanbal, 1995: 32/220).

Oleh karena itu pengetahuan dan pemahaman terhadap sumber daya alam juga sangat diperlukan, seperti potensi, kualitas zat, halal-haram dan lain-lain. Hal ini dilakukan agar setiap sumber daya alam tidak terbuang sia-sia. Rasulullah Saw pernah mengoreksi perbuatan sahabat yang hampir membuang bangkai kambing sedangkan kulitnya masih bisa dimanfaatkan, sebagaimana sabda Rasulullah Saw berikut ini:

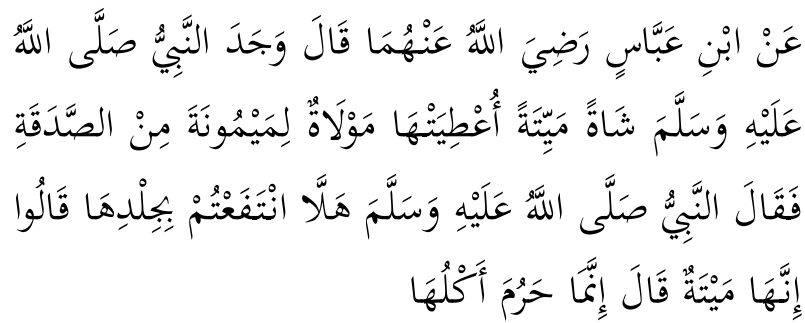

Ibnu 'Abbas Ra berkata: Nabi Saw mendapatkan seekor kambing yang diberikan oleh seorang sahaya wanita Maimunah sebagai zakatnya dalam keadaan mati. Maka Nabi Saw. bersabda: "Kenapa kalian tidak memanfaatkan kulitnya?'. Orang-orang berkata,: "Kambing itu sudah jadi bangkai". Beliau Saw menjawab: "Yang diharamkan itu memakannya" (AlBukhari, 1400: 1/462).

\section{PERINDUSTRIAN DI INDONESIA DALAM PRESPEKTIF EKOLOGI ALA NABI SAW}

\section{Ketimpangan Kesejahteraan}

Pembangunan nasional bertujuan untuk mewujudkan masyarakat adil dan makmur yang merata material dan spiritual berdasarkan Pancasila dan Undang-Undang Dasar Negara Republik
Indonesia Tahun 1945 dalam wadah Negara Kesatuan Republik Indonesia yang merdeka, bersatu, dan berkedaulatan rakyat dalam suasana perikehidupan bangsa yang aman, tertib, dan dinamis dalam lingkungan yang merdeka, bersahabat, dan damai (UU No. 20 Tahun 2008).

Salah satu sektor yang menopang hal ini adalah perindustrian. Berbagai langkah diambil pemerintah untuk mempermudah pertumbuhan dan perkembangan perekonomian terutama dunia industri. Kerangka-kerangka regulasi dievaluasi, direvisi, dan, diubah untuk agar terciptanya percepatan ekonomi. Mulai dari percepatan proses pengadaan tanah untuk kepentingan umum (UU No. 2 Tahun 2012), kemudahan izin usaha pertambangan (PP Perubahan atas PP No. 23 Tahun 2010), pengelolaan kawasan ekonomi khusus industri (PP No. 26 \& 29 Tahun 2012), pengadaan infrastruktur (Perpres No. 56 Tahun 2011), dan lain-lain.

Sekilas terlihat membahagiakan dan memberikan harapan baru untuk kesejahteraan rakyat Indonesia. Namun setelah ditelisik, langkah-langkah ini justru hanya akan memudahkan investor, bankir asing atau korporasi besar masuk dan meraup kekayaan alam Indonesia. Berbagai kemudahan ini justru tidak berpihak kepada pedagang kecil yang membuka lapak di emperan jalan, atau petani yang semakin hari semakin terampas lahannya untuk perkebunan sawit yang luasnya ratusan hektar (Noer Fauzi Rachman, 2014: 34).

Salah satu contoh adalah pengelolaan lahan seluas lebih dari 1,2 juta hektar di Merauke. Lebih dari seperempat wilayah Merauke sudah dikapling-kapling untuk dimanfaatkan oleh investor baik dari dalam negeri 
maupun asing. Satu perusahaan saja bisa menguasai puluhan ribu hektar bahkan hingga ratusan hektar. Pengusaan lahan skala luas ini ditopang oleh salah satu payung hukum yakni PP No. 18 Tahun 2010 tentang Usaha Budi Daya Tanaman. Pada pasal 8, ayat (2), disebutkan bahwa luas maksimum lahan untuk pengusahaan budidaya tanaman yaitu $10.000 \mathrm{Ha}$ (sepuluh ribu hektar). Namun ada wilayah yang secara khusus mendapat pengaturan berbeda. Untuk wilayah Papua, luas maksimum lahan dapat diberikan dua kali luas maksimum yang ditentukan untuk daerah lain (Noer Fauzi Rachman dkk: 2014: 74).

Inilah yang menjadi permasalahan klasik dan menjadi penyebab kemiskinan yang terjadi Indonesia dan negara berkembang pada umumnya. Terbatasnya akses kepemilikan aset tanah kelompok miskin karena rendahnya pendapatan mereka. Padahal tanah adalah salah satu faktor produksi penting dalam kehidupan ekonomi masyarakat. Kelompok masyarakat miskin cenderung tidak memiliki akses terhadap kepemilikan tanah. Posisi dan kepemilikan lahan/aset tanah justru cenderung dikuasai oleh kelompok minoritas pemegang kapital dan negara yang memiliki otoritas. Data statistik menunjukkan, jumlah kelompok miskin di pedesaan adalah para petani penggarap yang tidak memiliki lahan (Djaka Badranaya, 2011: 2).

\section{Lemahnya Pengawasan terhadap Kelestarian Sumber Daya Alam}

Pada dasarnya pemerintah sudah melakukan upaya untuk menjaga kelestarian sumber daya alam dengan mengeluarkan kebijakan-kebijakan dan menerbitkan Undang-undang untuk mengatur, menjaga, dan melestarikan alam sekaligus mendorong kemajuan perekonomian. Seperti UU No. 41 Tahun 1999 yaitu: Hutan merupakan sumber daya alam yang mempunyai berbagai fungsi, baik ekologi, ekonomi, sosial, maupun budaya yang diperlukan untuk menunjang kehidupan manusia dan makhluk hidup lainnya. Hutan memiliki tiga fungsi antara lain fungsi lindung, produksi, dan konservasi. Sebagai sumber daya alam yang memiliki fungsi lindung, hutan memberikan perlindungan sistem penyangga kehidupan untuk mengatur tata air, mencegah banjir, mengendalikan erosi, mencegah intrusi air laut, dan memelihara kesuburan tanah. Sebagai sumberdaya alam yang memiliki fungsi produksi, hutan mempunyai hasil-hasil hutan baik berupa kayu, bukan kayu, maupun produk turunannya, serta jasa lingkungan, yang dapat dimanfaatkan oleh manusia dan makhluk hidup lain untuk memenuhi kebutuhan hidup. Adapun fungsi konservasi dari hutan menjadikan hutan sebagai tempat untuk mengawetkan keanekaragaman tumbuhan, satwa, serta ekosistemnya.

Beberapa kebijakan lain juga dibuat dalam rangka mendukung proses industrialisasi di Indonesia, diantaranya pasal 33 UUD 1945, UU No. 23 / 1997 tentang Pengelolaan Lingkungan Hidup, UU No 22/ 2001 tentang Minyak dan Gas Bumi, UU No. 25/ 2007 tentang Penanaman Modal, UU No. 40/ 2007 tentang Perseroan Terbatas dan Peraturan Menteri BUMN No. 5 Tahun 2007 tentang Program Kemitraan BUMN dengan usaha kecil dan Program Bina Lingkungan.

Hanya saja peraturan-peraturan tersebut terlihat kontradiksi satu sama lain atau itu tidak terlihat hasil yang 
signifikan dalam prakteknya. Terlebih ketika adanya PP No. 60 dan 61 Tahun 2012 tentang Perubahan atas Peraturan Pemerintah No. 10 dan 24 Tahun 2010 tentang Tata Cara Perubahan Peruntukan dan Fungsi Kawasan Hutan yang terkesan melegitimasi kesalahan dan keterlanjuran penggunaan kawasan hutan untuk kegiatan non hutan. Begitu juga halnya dengan Perpres No. 28 Tahun 2011 tentang Penggunaan Kawasan Hutan Lindung untuk Penambangan Bawah Tanah sebagai aturan pelaksana dari PP No. 68 Tahun 1998 tentang Kawasan Pelestarian Alam dan Kawasan Suaka Alam juga memperlihatkan bahwa ada langkah memberi peluang lebih besar bagi kegiatan pertambangan untuk menggunakan kawasan hutan lindung (Noer Fauzi Rachman, 2014: 22 dan 52). Hal ini tentunya mempercepat investasi korporasi besar mengeruk kekayaan alam tanpa mempertimbangkan lagi keseimbangan alam.

Perubahan iklim, menipisnya lapisan ozon hingga berkurangnya luas hutan tropis merupakan dampak dari penggunaan energi dan bahan kimia yang tidak seimbang selain dari pembabatan hutan secara liar (baca-illegal logging). Proses penambangan yang mengganggu daerah resapan air, limbah beracun hingga krisis air bersih akibat proses ekstraksi pertambangan menjadi bukti lemahnya pengawasan terhadap dunia industri yang berdampak pada kelestarian lingkungan dan sumber daya alam. Belum lagi rusaknya ekosistem laut berupa tercemarnya hutan mangrove, rusaknya terumbu karang, dan lain sebagainya.

Kawasan perairan dari teluk Tomori yang merupakan bekas ibu kota sementara Kabupaten Morowali adalah salah satu koban dari 'pesta pora nikel'.
Laut penghasil ikan itu ditimbun dengan tanah merah dari pegunungan sekitar, sebagai material untuk membangun port (pelabuhan) parkiran tongkang biji nikel. Tidak hanya satu, sedikitnya kurang lebih 15 pelabuhan sejenis (reklamasi pantai) berjejer di antara gugusan pulau-pulau kecil yang berakhir di garis hutan mangrove Cagar Alam Morowali. Permukaan laut yang dulu biru nan eksotik dalam ekosistem tropis, dikelilingi gugusan-gugusan gunung dan bukit yang hijau, seketika berubah warna, seperti minuman orange. Karamba-karamba ikan milik nelayan yang berada di bibir pantai, ikut berubah warna. Ikan-ikan berkelas nampak mengapung di malam hari disinari cahaya lampu kendaraan operasional perusahaan tambang dari arah pegunungan, yang mengejar waktu jatuh tempo muatan kapal. Perubahan lanskap berlangsung dalam kurun waktu singkat, sejak Undang-undang Mineral dan Batubara tahun 2009 diterbitkan. Dari satu desa ke desa lainnya, kecamatan ke kecamatan lainnya, dalam satuan administrasi Morowali, pesat dengan rencana pembukaan lokasi tambang. Kondisi perairan di Teluk Tomori wajahnya tak lebih 'bopeng' dari desadesa sekitar Bahodopi dan Bungku Timur. Mulut pantai telah berubah menjadi sandaran tongkang, hutan bakau yang menekan abrasi pantai kini dibabat dan ditimbun. Sekeliling pelabuhan itu dipagari menggunakan kayu yang ditebang dari blok-blok galian tambang (Noer Fauzi Rachman dkk, 2014: 86).

Selain itu, dampak industri tidak hanya berdampak pada lingkungan alam, akan tetapi juga berpengaruh secara tak langsung pada sosial masyarakat seperti urbanisasi, perubahan prilaku, sosial 
budaya, dan kriminalitas (Wisnu Arya Wardhana, 2004: 20). Ketimpangan sosial antara kota dan desa membuat masyarakat pedesaan memilih pindah ke kota dengan harapan menikmati hidup lebih sejahtera di daerah perkotaan. Hiruk pikuk perkotaan di tengah tumpukan pekerjaan membuat stres tingkat tinggi hingga tak jarang membuat pelakunya mencari pelarian tak bermutu untuk mengurangi ketegangan. Semua hal ini menyebabkan perubahan perilaku dan sosial budaya. Bahkan tak jarang semua ketegangan ini memicu naiknya angka kriminalitas.

\section{Overakumulasi Kapital}

Jika Islam mengajarkan proporsional dalam kegiatan produksi tidak berlebihlebihan dan tidak terbuang sia-sia, maka kebalikannya adalah terus melakukan kegiatan produksi tanpa memperhatikan ketepatan guna hasil produksi, atau surplus produk di pasaran yang tidak bisa dimanfaatkan kembali atau tidak mempertimbangkan pemerataan hasil produksi sehingga bertumpuk pada satu tempat dan kosong pada tempat lain. Melihat perkembangan perindustrian di Indonesia, maka dapat dilihat sistem yang digunakan lebih cenderung menggunakan sistem kapital.

Kapital adalah suatu proses dan cara produksi dimana uang mesti digerakkan untuk memperoleh uang yang lebih banyak (money-commodity-more money). Dalam cara produksi kapitalis, proses itu tak bisa berhenti dan berlaku sekali saja, ia harus selalu merupakan proses akumulasi keuntungan yang tanpa henti (endless accumulation) dan harus selalu menghilangkan hambatan supaya proses akumulasi itu dapat mengalami pembesaran dan perluasan (boundless accumulation). Kapital juga adalah relasi sosial, yaitu hubungan antara kelas kapitalis dan kelas buruh dalam suatu proses kerja dimana untuk memperoleh uang lebih banyak (laba), kelas kapitalis mengeksploitasi dan menghisap kelas buruh. Tetapi, cara produksi kapitalis yang sedemikian itu selalu menghasilkan krisis, yang disebut dengan dengan krisis overakumulasi. Krisis bukan berarti ketiadaan uang atau barang, malahan, ia adalah kondisi dimana keberlimpahan uang dan barang terjadi. Krisis overakumulasi dapat tampil dalam berbagai bentuk yaitu: overproduksi komoditas, yaitu berlimpahnya dan berlebihnya barang-barang dagangan di pasar; jatuhnya tingkat keuntungan; surplus kapital, yaitu melimpahnya uangkapital yang tidak dapat diinvestasikan kembali serta ketiadaan kesempatan bagi uang-kapital untuk memperoleh keuntungan dari proses produksi; surplus tenaga kerja, yaitu melimpahnya tenaga kerja yang tak dapat diserap dalam proses produksi dan atau dapat berupa meningkatnya level eksploitasi tenaga kerja (Noer Fauzi Rachman dkk, 2014: 32).

Salah satu contoh adalah Pulau Gebe, adalah Pulau pertama di Kep. Halmahera yang ditambang untuk nikel. Tahun 1973, PT Endiko Jepang mulai menambang di sana. Tahun 1979 PT ANTAM mulai masuk dan menambang hingga Tahun 2003, katanya persediaan nikelnya habis, Antam pergi dan mulai direboisasi. Tidak sampai setahun PT Gebe Karya Mandiri mengemasi sisa-sisa nikel yang masih bisa dikeruk. Sekarang, hampir 3000 jiwa penduduk Pulau Gebe merana kelaparan, karena ladang sagu mereka telah berubah jadi kubangan- 
kubangan besar (Noer Fauzi Rachman dkk, 2014: 208). Selain itu, beberapa kasus korupsi kelas kakap yang ditangani oleh KPK juga berupa eksploitasi sumber daya alam. (detik.com, 2015)

\section{PENUTUP}

Sebagai negara yang mayoritas penduduknya adalah muslim, terlihat belum maksimalnya peran agama dalam memberikan pengaruh pemikiran terhadap perkembangan perindustrian di Indonesia. Motivasi Rasulullah Saw untuk produksi yang bertujuan untuk kesejahteraan rakyat berbanding terbalik dengan kondisi masyarakat yang tinggal bahkan tidak jauh dari industri tersebut. Tidak adanya pengawasan terhadap kebijakan pelestarian alam termasuk sumber daya alam semakin menjauhkan kita dari kata berbuat baik (ihsan) terhadap alam. Eksploitasi besar-besaran dalam dunia pertambangan hanya menyisakan krisis ekologi berupa pencemaran dan krisis sosial berupa ketimpangan kesejahteraan.

\section{DAFTAR KEPUSTAKAAN}

Al-Baihaqi, Ahmad Ibn Husein, 1989. alSunan al-Shaghir. Karachi: Jami'ah alDirasah al-Islamiy-yah.

Al-Bukhari, Muhammad Ibn Isma'il. 1400. Al-Jami' al-Shahih, Cairo: Maktabah al-Salafiyyah

Al-Naisaburi, Muslim Ibn al-Hajjaj. 1991. Shahih Muslim, Cairo: Maktabah Dar Ihya al-Kutub al-'Arabiyyah.

Al-Qaradhawi, Yusuf. 2001. Ri'ayah alBi'ah FI Syari'at al-Islam, Cairo: Dar al-Syuruq.
Al-Sijistani, Abu Daud. 1998. Sunan Abi Daud, Beirut: Mu`assasah al-Rayyan.

Djaka Badranaya. 2011. Pemanfaatan Lahan Telantar dalam Tinjauan UndangUndang Pokok Agraria Dan Ekonomi Islam, Al-Iqtishad: Vol. III, No. 2, Juli 2011.

Fajar Pratama, 12 April 2015, 5 Kasus Korupsi Kakap Eksploitasi Sumber Daya Alam yang Ditangani KPK, (http://www.detik.com.) diakses 20 Agustus 2016.

Hanbal, Ahmad Ibn. 1995. Musnad Ahmad Ibn Hanbal, Beirut: Mu`assasah alRisalah.

Noer Fauzi Rachman dkk. 2014. MP3EI Master Plan Percepatan Dan Perluasan Krisis Sosial-Ekologis Indonesia, Yogyakarta: Tanah Air Beta.

Republik Indonesia. 1999. UndangUndang No. 41 Tahun 1999 tentang Kehutanan, Lembaran Negara RI Tahun 1999 No. 167, Jakarta: Sekretariat Negara.

Republik Indonesia. 2008. Undangundang Nomor 20 Tahun 2008 tentang Usaha Mikro, Kecil dan Menengah, Lembaran Negara RI Tahun 2008, No. 93. Jakarta: Sekretariat Negara.

Republik Indonesia. 2010. Peraturan Pemerintah Republik Indonesia No. 18 Tahun 2010 tentang Usaha Budidaya Tanaman, Lembaran Negara RI Tahun 2010 No. 24, Jakarta: Sekretariat Negara

Wardhana, Wisnu Arya. 2004. Dampak Pencemaran Lingkungan, Yogyakarta: Andi Offset. 
